\title{
Evaluation of biological potential of selected species of family Poaceae from Bahawalpur, Pakistan
}

\author{
Iram Fatima', Sobia Kanwal ${ }^{2}$ and Tariq Mahmood ${ }^{1 *}$
}

\begin{abstract}
Background: Oxidative stress as well as bacterial and fungal infections are common source of diseases while plants are source of medication for curative or protective purposes. Hence, aim of study was to compare the pharmacological potential of seven grass species in two different solvents i.e. ethanol and acetone.

Methods: Preliminary phytochemical tests were done and antioxidant activities were evaluated using ELISA and their IC50 values and AAI (\%) were recorded. ANOVA was used for statistical analyses. DNA damage protection assay was done using p1391Z plasmid DNA and DNA bands were analyzed. Antimicrobial activity was done via disc diffusion method and MIC and Activity Index were determined. Cytotoxic activity was carried out using the brine shrimps' assay and LC50 values were calculated using probit analysis program.
\end{abstract}

Results: Phytochemical studies confirmed the presence of secondary metabolites in most of the plant extracts. Maximum antioxidant potential was revealed in DiAEE, DiAAE (AAI- 54.54\% and 43.24\%) and DaAEE and DaAAE (AAl- 49.13\% and 44. 52\%). However, POAEE and PoAAE showed minimum antioxidant potential (AAI- 41.04\% and 34.11\%). SaSEE, DiAEE and ElIEE showed very little DNA damage protection activity. In antimicrobial assay, DaAEE significantly inhibited the growth of most of the microbial pathogens (nine microbes out of eleven tested microbes) among ethanol extracts while DaAAE and ImCAE showed maximum inhibition (eight microbes out of eleven tested microbes) among acetone plant extracts. However, POAEE and POAAE showed least antimicrobial activity. F. oxysporum and A. niger were revealed as the most resistant micro-organisms. ImCEA and ImCAE showed maximum cytotoxic potential (LC50 11.004 ppm and 7.932 ppm) as compared to the other plant extracts.

Conclusion: Fodder grasses also contains a substantial phenols and flavonoids contents along with other secondary metabolites and, hence, possess a significant medicinal value. Ethanol extracts showed more therapeutic potential as compared to the acetone extracts. This study provides experimental evidence that the selected species contains such valuable natural compounds which can be used as medicinal drugs in future.

Keywords: Fodder grasses, Phytochemical analysis, Antioxidant activity, p1391Z plasmid DNA, Antibacterial activity, Antifungal activity, Brine shrimps' Cytotoxicity

\footnotetext{
* Correspondence: tmahmood@qau.edu.pk; tmahmood.qau@gmail.com ${ }^{1}$ Department of Plant Sciences, Faculty of Biological Sciences, Quaid-i-Azam University, Islamabad 45320, Pakistan

Full list of author information is available at the end of the article
}

\section{Ciomed Central}

(c) The Author(s). 2018 Open Access This article is distributed under the terms of the Creative Commons Attribution 4.0 International License (http://creativecommons.org/licenses/by/4.0/), which permits unrestricted use, distribution, and reproduction in any medium, provided you give appropriate credit to the original author(s) and the source, provide a link to the Creative Commons license, and indicate if changes were made. The Creative Commons Public Domain Dedication waiver (http://creativecommons.org/publicdomain/zero/1.0/) applies to the data made available in this article, unless otherwise stated. 


\section{Background}

Herbal drugs have got a distinct place since ancient times. Both human and plant use history are of a similar age yet the proof concerning the use of plants is found in Ayurveda between 2500 and 600 BC [1]. The diverse medicinal plants are utilized for food and treatment of various ailments from their discovery. Certainly, Pakistan is a well-develop ecological zone, in which medicinal plants are utilized as a medicine for human as well as animals. Bahawalpur region is in one of the nine divisions of the Punjab province and its total area is 18,000 sq. miles. Bahawalpur was constructed on the southern bank of Sutlej River [2]. Poaceae or the grass family is the fifth largest family of flowering plants containing about 50 tribes, 660 genera and 10,000 species [3]. In Pakistan, Poaceae is represented by 158 genera and 492 species [4] and is of incredible economic and medicinal importance. Some plants of family Poaceae are used as a medication for hypertension, antidiabetic, anti-inflammatory, anthelmintic, antiulcer, diuretic and antioxidant [5].

Dichanthium annulatum (Forsk.) Stapf, generally known as 'marvel grass' is classified within the Order of Poales and is used as forage due to its simple and cheaper development from seed [6]. The grass is also used for dysentery and menorrhagia [7]. Eleusine indica L. is commonly known as 'wire grass or goose grass' and is used in traditional medicine as a diuretic, antihelminthic, anti-cancer, febrifuge, hypertension, kidney problems and for treating influenza and cough $[8,9]$. Similarly, Poa annua L. (annual bluegrass) is a cosmopolitan weed with a high genotypic and phenotypic variability. Dactyloctenium aegyptium L. has anti-oxidant, anti-inflammatory, anticancer, antipyretic properties and antimicrobial activity and is used for treating small pox, wounds and ulcers [10].

Saccharum spontaneum L. generally known as 'wild sugarcane' is used to treat diseases such as vomiting, anaemia, abdominal disorders and obesity. The roots are used as astringent, emollient, diuretic, tonic and for treating dyspepsia, burning sensation, piles, respiratory troubles etc. [11]. Leaves are employed for cathartic and diuretics. However, the whole plant possesses antidiarrheal, CNS depressant and antiurolithiatic activity $[12,13]$. Vetiveria zizanioides (L.) is usually known as 'Khas-Khas' and has thick adventitious roots which are stimulant, stomachic and used in fevers and inflammations [14]. Vetiver grass is also grown for the production of oil which is used in perfumery and aromatherapy [15]. Imperata cylindrica L., commonly known as thatch grass or cogon grass, possess immunomodulatory, neuroprotective, anticancer, and antioxidant activities [16, 17].

To date, a few studies of the selected grass species relevant to their antifungal, antioxidant and brine shrimps' cytotoxic activity have been reported. Natural products require strong evaluation of their pharmacological abilities. Accordingly, this study was conducted to assess the biological potential and DNA damage protection assay of the selected grasses collected from different areas of Bahawalpur to evaluate their pharmacological potential.

\section{Methods}

Collection and preparation of plant extracts

D. annulatum (Acc. No. 129851), E. indica (Acc. No. 129854), P. annua (Acc. No. 129850), D. aegyptium (Acc. No. 129846), S. spontaneum (Acc. No. 129841), V. zizanioides (Acc. No. 129844) and I. cylindrica (Acc. No. 129842) were collected from Lal Suhanra National Park and Islamia University of Bahawalpur, Pakistan during the month of March, 2016 and accession numbers were allotted by Herbarium of Pakistan, Quaid-e-Azam University, Islamabad. Aerial parts of plants were selected because of their ethno-medicinal importance. Plants were washed, air-dried, powdered and extracted with ethanol and acetone (50 g/500 mL each) for two days and then filtered and evaporated using a rotary evaporator (BUCHI Rotavapor $\mathrm{R}-220)$ and then stored at $4{ }^{\circ} \mathrm{C}$ for further use [18].

\section{Preliminary phytochemical tests}

Various qualitative tests are performed for establishing profile of the plant extracts for its chemical composition. So, preliminary phytochemical tests of the plant extracts were done to confirm the presence of secondary metabolites, using standard procedures for the detection of alkaloids (Mayer's reagent), cardiac glycosides (Salkowski test), saponins (Foam test), flavonoids (Alkaline reagent test), phenols (Ferric chloride test), tannins (Gelatin test), steroids and terpenoids (Libermann's test), anthocyanins $\left(2 \mathrm{ml}\right.$ extract $+2 \mathrm{ml} \mathrm{HCl}+\mathrm{NH}_{3}-$ pinkish red to bluish violet colour) and coumarins $(2 \mathrm{ml}$ extract $+3 \mathrm{ml}$ $\mathrm{NaOH}$ - yellow colour) $[18,19]$.

\section{Total phenols and flavonoids contents}

The content of total phenols was determined using FolinCiocalteu reagent [20]. Calibration curve was made by mixing gallic acid with $90 \mu \mathrm{l}$ of Folin-Ciocalteu reagent and $90 \mu \mathrm{l}$ of $\mathrm{NaCO}_{3}$ solution. Similarly, $20 \mu \mathrm{l}$ of plant extracts were mixed with the same reagent and the absorbance was measured. Total phenolic contents were expressed as gallic acid equivalents (mg GAE/g sample). Total flavonoids were measured using Aluminum Chloride Colorimetric Method and total content of flavonoids was expressed as quercetin equivalents (mg of QE/g sample) [21].

\section{Antioxidant activity determination $D P P H$ radical scavenging activity}

$180 \mu \mathrm{l}$ of DPPH solution was added to a $20 \mu \mathrm{l}$ of sample solution and activity was measured at different concentrations 
(10, 20 and $40 \mu \mathrm{g} / \mathrm{ml})$. After $60 \mathrm{~min}$, absorbance at $515 \mathrm{~nm}$ was measured and the percentage of radical scavenging activity was determined [22]:

$$
\% \text { scavenging activity }=\frac{\mathrm{Abs}_{\mathrm{control}}-\mathrm{Abs}_{\text {sample }}}{\mathrm{Abs}_{\text {control }}} \times 100
$$

$\mathrm{Abs}_{\text {control }}$ is absorbance of the DPPH solution without sample and $\mathrm{Abs}_{\text {sample }}$ is absorbance of tested plants. Ascorbic acid was used as a standard antioxidant. IC50 value was also measured.

\section{ABTS radical scavenging assay}

ABTS radical cation was prepared by mixing $7 \mathrm{mM}$ ABTS stock solution with $2.45 \mathrm{mM}$ Potassium persulphate and after $12-16 \mathrm{~h}, \mathrm{ABTS}^{+}$solution was diluted to an absorbance of $0.700 \pm 0.02$ at $734 \mathrm{~nm}$. $160 \mu \mathrm{l}$ of $\mathrm{ABTS}^{+}$solution and $10 \mu \mathrm{l}$ of different plant concentrations were mixed and absorbance was taken at $734 \mathrm{~nm}$ and IC50 values were determined [23].

\section{NBT (superoxide radical scavenging) assay}

$1 \mathrm{~mL} \mathrm{Na}_{2} \mathrm{CO}_{3}$ and $0.4 \mathrm{~mL} \mathrm{NBT}$ were added in $1 \mathrm{~mL}$ of each extract solution. Then $0.2 \mathrm{~mL}$ EDTA solution and $0.4 \mathrm{~mL} \mathrm{mM}$ hydroxylamine hydrochloride were added. After $15 \mathrm{~min}$ of incubation at $25{ }^{\circ} \mathrm{C}$, absorbance was taken at $540 \mathrm{~nm}$. \% inhibition and IC50 value will be determined.

\section{Reducing power assay}

$200 \mu \mathrm{L}$ extract was added with $500 \mu \mathrm{L}$ phosphate buffer and $500 \mu \mathrm{L}$ potassium ferricyanide. Reaction mixture was incubated at $50^{\circ} \mathrm{C}$ and TCA $(500 \mu \mathrm{L})$ was added and centrifuged for $10 \mathrm{~min}$. Supernatant was mixed with $100 \mu \mathrm{L}$ of $0.1 \% \mathrm{FeCl}_{3}$ and the absorbance was measured [24].

\section{Cupric ions reducing antioxidant capacity (CUPRAC)}

$10 \mu \mathrm{l}$ of $0.01 \mathrm{M} \mathrm{CuCl}_{2}$ solution, $10 \mu \mathrm{l}$ of $7.5 \mathrm{mM}$ ethanol neocuproine solution, and $10 \mu \mathrm{l}$ of $1.0 \mathrm{M}$ ammonium acetate buffer solution were added to $20 \mu \mathrm{l}$ of gallic acid and plant extracts. Finally, total volume was adjusted to $1 \mathrm{~mL}$ with $\mathrm{dH}_{2} \mathrm{O}$ and absorbance was measured at $515 \mathrm{~nm}$ [25].

\section{Phosphomolybdate assay}

TAC was evaluated by method proposed by Prieto et al. [26]. In this assay, $50 \mu \mathrm{l}$ of extract was incubated with $500 \mu$ l of reaction mixture $(28 \mathrm{mM}$ sodium phosphate, $0.6 \mathrm{M}$ sulfuric acid and $4 \mathrm{mM}$ ammonium molybdate) for $90 \mathrm{~min}$ at $95{ }^{\circ} \mathrm{C}$ in water bath, and absorbance was measured.

\section{Antioxidant activity index (AAI)}

Antioxidant activity index was calculated as it denotes the average of the results based on the six methods used for evaluation of antioxidant activity, namely, $\mathrm{DPPH}$, ABTS, SOR, TRP, CUPRAC and phosphomolybdate assay [27].

\section{DNA damage protection assay}

$3 \mu \mathrm{L}$ of p1391Z plasmid DNA was mixed with $5 \mu \mathrm{L}$ of Fenton's reagent and different concentrations of plant extracts and the final volume was brought up to $15 \mu \mathrm{L}$ using $\mathrm{dH}_{2} \mathrm{O}$. The reaction mixtures were then incubated for $30 \mathrm{~min}$ at $37{ }^{\circ} \mathrm{C}$ and bromophenol blue dye was added. The reaction mixtures $(15 \mu \mathrm{L})$ were loaded on $0.4 \%$ agarose gel and electrophoresis was carried out followed by ethidium bromide staining. After that DNA bands were analyzed [28].

\section{Antimicrobial assay}

Bacterial and fungal strains were collected from the Department of Microbiology, Quaid-i-Azam University, Islamabad and propagated in Plant Biochemistry and Molecular Biology Laboratory, Quaid-i-Azam University, Islamabad, Pakistan. Bacterial strains include $S$. aureus (ATCC 2593), L. monocytogenes (ATCC 13932), B. spizizenii (ATCC 6633), S. typhi (ATCC 1428) and E. coli (ATCC 25922). The fungal pathogens include $W$. anomalus, $F$. oxysporum, Mucor sp., A. flavus, A. niger and S. cerevisae. Bacterial isolates were sub-cultured in a nutrient broth and then incubated at $37{ }^{\circ} \mathrm{C}$ for $18 \mathrm{~h}$ while the fungal isolates were sub-cultured on SDA media for $24 \mathrm{~h}$ at $25^{\circ} \mathrm{C}$. Antibacterial and antifungal assay were performed via agar disc diffusion method. Oxytetracycline and Chloramphenicol were used as a positive control [29, 30]. The zones $<8 \mathrm{~mm}$ were not considered significant. MIC and Activity index for each extract was calculated.

\section{Cytotoxic brine shrimp assay}

Six different concentrations of plant extracts (i.e 6, 12, $25,50,100$ and $250 \mu \mathrm{g} / \mathrm{mL}$ ) were added in each vial and their final volume was brought to $5 \mathrm{~mL}$ with the help of saline solution. After $24 \mathrm{~h}$, ten shrimps were transferred to each vial and were incubated at $32{ }^{\circ} \mathrm{C}$ for $24 \mathrm{~h}$, after which the survivors were counted [31]. LC50 values and $\%$ mortality were calculated.

\section{Statistics}

Each experiment was performed at least three times, and mean \pm standard error (SE) was measured. Results of phytochemical tests and antioxidant activity were subjected to ANOVA using Statistix version 8.1 and comparison among mean values was made by LSD [32]. Graphpad prism was used to calculate IC50 values. LC50 values were calculated using probit analysis program and were assessed at 95\% confidence interval [33]. Densitometry calculation of DNA bands was done with the help of ImageJ software. 


\section{Results}

Qualitative analysis of phytochemicals and determination of total phenols and flavonoids contents

Preliminary phytochemical tests of selected plants revealed that various secondary metabolites are strongly present in most of the ethanol plant extracts as compared to the acetone plant extracts. Flavonoids and phenols were strongly present in all selected plant extracts while alkaloids and terpenoids were weakly present in all plant extracts. Glycosides and steroids were present in all species except in DiAAE and ElIAE. Anthocyanin and saponins were detected in all samples except in SaSAE. Tannins was strongly present in DaAEE, DaAAE, ImCEE and ImCAE as compared to the other plants excluding PoAEE and PoAAE in which tannins were not present. However, coumarins were found in all plant extracts except in SaSAE (Table 1).

The quantitative analysis of the selected plant extracts revealed that in case of ethanol plant extracts VeZEE and ElIEE $(211.017 \pm 18.51 \mathrm{mg} \mathrm{GAE} / \mathrm{g}$ and $201.115 \pm$ $11.61 \mathrm{mg}$ GAE/g) exhibited maximum phenolic contents while DiAEE and ElIEE (47.023 $\mathrm{mg} / \mathrm{g} \pm 4.56 \mathrm{mg} \mathrm{QE} / \mathrm{g}$ and $32.621 \pm 2.89 \mathrm{mg} \mathrm{QE} / \mathrm{g}$ ) revealed maximum flavonoids contents. However, among acetone plant extracts, VeZAE and SaSAE $(217.022 \pm 10.38 \mathrm{mg}$ GAE/g and $215.723 \pm 11.98 \mathrm{mg}$ GAE$/ \mathrm{g}$ ) possess maximum phenolic contents while VeZAE and PoAAE $(28.108 \pm 2.55 \mathrm{mg}$ $\mathrm{QE} / \mathrm{g}$ and $27.385 \pm 2.88 \mathrm{mg} \mathrm{QE} / \mathrm{g}$ ) exhibited maximum flavonoid contents (Fig. 1).

\section{Antioxidant activities}

Antioxidant activity is a parameter used to assess therapeutic efficacy of plants as it scavenges free radicals in a specific reaction medium. The free radicals including DPPH, ABTS and SOR scavenging activity of respective plant extracts was determined and compared with standard antioxidant (ascorbic acid). In DPPH assay, IC50 value of ascorbic acid (positive control) was recorded as
$16.913 \pm 2.57 \mu \mathrm{g} / \mathrm{ml}$. IC50 values of the selected species for radicals scavenging activities are presented in Table 2. The lower the IC50, the stronger the scavenging activity. In present studies, among ethanol plant extracts DiAEE showed stronger DPPH radical scavenging activity (IC50 $32.803 \pm 9.66 \mu \mathrm{g} / \mathrm{ml}$ ) while PoAEE showed minimum DPPH scavenging activity (IC50 $107.506 \pm 9.60 \mu \mathrm{g} / \mathrm{ml}$ ). In case of acetone plant extracts, VeZAE showed stronger DPPH radical scavenging activity (IC50 78.48 \pm $7.79 \mu \mathrm{g} / \mathrm{ml}$ ) while ImCAE showed minimum DPPH scavenging activity (IC50 $408.9 \pm 8.16 \mu \mathrm{g} / \mathrm{ml}$ ). Moreover, analysis of variance indicated significant variations among various plant species.

IC50 values of positive control (ascorbic acid) in ABTS assay and SOR assay was recorded as $2.804 \pm 0.29 \mu \mathrm{g} / \mathrm{ml}$ and $32.25 \pm 4.67 \mu \mathrm{g} / \mathrm{ml}$. In ABTS radical scavenging activity, maximum activity was detected in ethanol extract of SaSEE (IC50 $3.696 \pm 3.30 \mu \mathrm{g} / \mathrm{ml}$ ) and minimum activity was observed in DaAEE (IC50 $22.716 \pm$ $3.14 \mu \mathrm{g} / \mathrm{ml}$ ). However, among acetone plant extracts, maximum radical scavenging activity was revealed in DaAAE (IC50 $17.093 \pm 2.43 \mu \mathrm{g} / \mathrm{ml}$ ) and minimum activity was found in PoAAE (IC50 $50.793 \pm 9.74 \mu \mathrm{g} / \mathrm{ml}$ ). In SOR assay, among ethanol plant extracts, maximum scavenging activity was present in DiAEE (IC50 64.526 $\pm 9.41 \mu \mathrm{g} / \mathrm{ml}$ ) and minimum activity was observed in VeZEE (IC50 $105.833 \pm 5.15 \mu \mathrm{g} / \mathrm{ml})$. However, in case of acetone extracts, maximum activity was detected in ElIAE (IC50 $44.013 \pm 5.45 \mu \mathrm{g} / \mathrm{ml}$ ) and minimum activity in PoAAE (IC50 237.8 $\pm 8.88 \mu \mathrm{g} / \mathrm{ml}$ ). Overall, ethanol plant extracts showed remarkably stronger free radicals scavenging activity as compared to the acetone plant extracts. Moreover, strong SOR scavenging activity of DiAEE, EIIEE and EIIAE statistically similar to the standard ascorbic acid revealed strong antioxidant fractions in these extracts (Table 2).

In reducing power assay and CUPRAC assay, the higher absorbance indicates stronger antioxidant activity.

Table 1 Qualitative analysis of phytochemicals of selected plants

\begin{tabular}{|c|c|c|c|c|c|c|c|c|c|c|c|c|c|c|}
\hline Phytochemi-cals & DiAEE & DiAAE & EllEE & ElIAE & POAEE & POAAE & DaAEE & DaAAE & SaSEE & SaSAE & VeZEE & VeZAE & ImCEE & ImCAE \\
\hline Alkaloids & ++ & + & +++ & ++ & + & - & +++ & +++ & - & - & +++ & + & +++ & + \\
\hline Flavonoids & +++ & ++ & +++ & ++ & ++ & ++ & +++ & +++ & +++ & +++ & +++ & +++ & +++ & ++ \\
\hline Glycosides & +++ & - & +++ & - & ++ & ++ & ++ & ++ & +++ & ++ & ++ & ++ & ++ & ++ \\
\hline Phenols & ++ & + & +++ & ++ & ++ & + & +++ & +++ & +++ & +++ & +++ & ++ & +++ & + \\
\hline Steroids & ++ & - & + & - & ++ & + & + & ++ & +++ & ++ & +++ & ++ & ++ & ++ \\
\hline Terpenoids & + & + & + & + & + & + & ++ & + & ++ & + & ++ & + & ++ & + \\
\hline Saponins & +++ & - & +++ & - & +++ & - & +++ & + & ++ & + & +++ & ++ & +++ & + \\
\hline Tannins & + & + & + & ++ & - & - & +++ & +++ & ++ & + & + & + & +++ & ++ \\
\hline Anthocyanin & +++ & +++ & +++ & +++ & +++ & + & +++ & +++ & + & - & ++ & + & ++ & + \\
\hline Coumarin & ++ & + & +++ & ++ & +++ & + & +++ & + & +++ & - & +++ & ++ & +++ & ++ \\
\hline
\end{tabular}

+++ Strongly present; ++Moderately present; + Weakly present; - Absent 
$\varpi \mathrm{TPC}($ Ethanol $) \varpi \mathrm{TPC}($ Acetone $) \varpi \mathrm{TFC}($ Ethanol $) \llbracket \mathrm{TFC}($ Acetone $)$

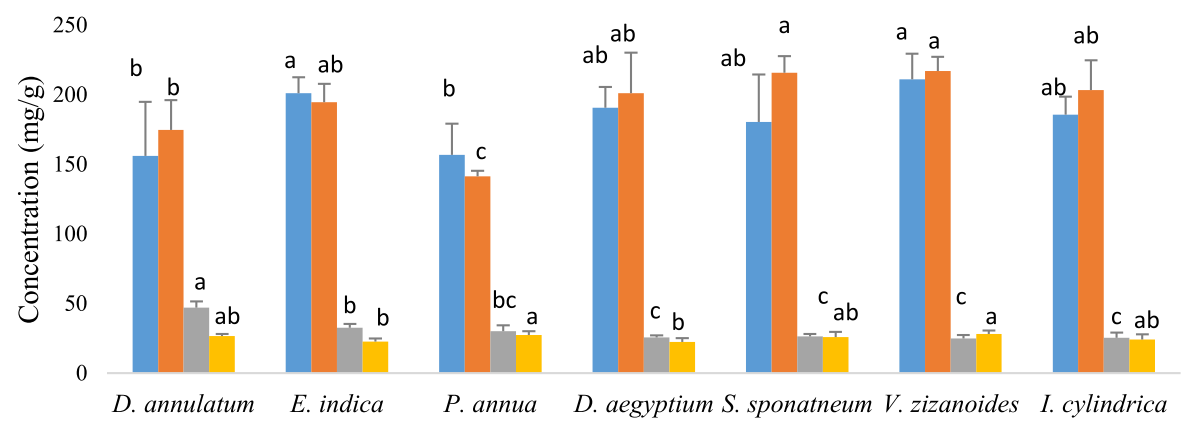

TPC and TFC of selected plant extracts

Fig. 1 TPC and TFC in selected plant extracts. Data represents the mean of three replicates and each letter (a-c) indicates significance at $P<0.05$

Among ethanol plant extracts, maximum reducing power ability was found in DaAEE $(35.107 \pm 1.07 \mathrm{mg} / \mathrm{g})$ and minimum in VeZEE $(23.889 \pm 0.87 \mathrm{mg} / \mathrm{g})$. However, among acetone plant extracts, maximum reducing power ability was found in PoAAE $(30.029 \pm 0.77 \mathrm{mg} / \mathrm{g})$ and minimum in VeZAE $(17.009 \pm 2.86 \mathrm{mg} / \mathrm{g})$ respectively (Fig. 2). Similarly, cupric ion reducing power of the ethanol plant extracts ranked in decreasing order of DiAEE > DaAEE > EIIEE $>$ SaSEE $>$ VeZEE $>$ ImCEE > PoAEE $(125.281 \pm$ $4.53,109.718 \pm 4.75,102.953 \pm 1.9,84.129 \pm 3.96,80.796 \pm$ $2.8,78.174 \pm 1.34,61.850 \pm 3.78 \mathrm{mg} / \mathrm{g}$ ). However, cupric ion reducing power of the acetone plant extracts was found in decreasing order of EIIAE $>$ DiAAE $>$ SaSAE $>$ DaAAE $>$ VeZAE $>$ ImCAE > PoAAE $(97.438 \pm 1.38,92.365 \pm 1.84$, $86.580 \pm 4.19, \quad 86.482 \pm 3.42, \quad 85.723 \pm 3.96, \quad 84.914 \pm 2.73$, $57.389 \pm 1.97 \mathrm{mg} / \mathrm{g}$ ) respectively (Fig. 2). These values of CUPRAC assay were determined from the regression equation obtained from positive control i.e. gallic acid $(y=$ $0.0136 x+0.0845)$.

The results obtained from phosphomolybdate assay show that ethanol extract has potent ability to reduce $\mathrm{Mo}(\mathrm{VI})$ to $\mathrm{Mo}(\mathrm{V})$ as compared to the acetone extracts. In comparing ethanol plant extracts, total antioxidant capacity was observed maximum in ImCEE (45.815 \pm $0.86 \mathrm{mg} / \mathrm{g})$ and minimum in DiAEE $(31.626 \pm 0.72 \mathrm{mg} / \mathrm{g})$ while among acetone plant extracts total antioxidant capacity was found maximum in DiAAE (55.807 \pm $0.62 \mathrm{mg} / \mathrm{g})$ and minimum in ElIAE $(39.502 \pm 2.26 \mathrm{mg} / \mathrm{g})$. These values were determined from the regression equation obtained from standard ascorbic acid curve $(y=$ $0.0405 x+0.3588$ ). Analysis of variance also showed significant variations among selected plant species (Fig. 2).

\section{Antioxidant activity index (AAI)}

The Antioxidant Activity Index was used to rate the selected plant species on the basis of antioxidant potential. Some plants showed variable antioxidant potential in different assays. For example, DiAEE was revealed as a potent antioxidant by DPPH scavenging assay, ABTS scavenging assay, SOR scavenging assay and Cupric ions reducing assay but moderate or weak antioxidant by total antioxidant assay and total reducing power assay. Owing to such difficulty in analyzing results from each assay, Antioxidant Activity Index (AAI) in terms of percentage was determined to combine the average results of six assays for evaluation of antioxidant capacity.

Table 2 Evaluation of IC50 values of free radical scavenging activities

\begin{tabular}{|c|c|c|c|c|c|c|}
\hline \multirow[t]{2}{*}{ Plant material } & \multicolumn{2}{|c|}{ DPPH radical scavenging activity } & \multicolumn{2}{|c|}{ ABTS radical scavenging activity } & \multicolumn{2}{|c|}{$\underline{\text { SOR scavenging activity }}$} \\
\hline & Ethanol & Acetone & Ethanol & Acetone & Ethanol & Acetone \\
\hline D. annulatum & $32.803 \pm 9.66^{\mathrm{D}}$ & $390.4 \pm 5.40^{B}$ & $3.897 \pm 1.21^{\mathrm{D}}$ & $31.26 \pm 8.73^{B}$ & $64.526 \pm 9.41^{B}$ & $70.403 \pm 3.98^{\mathrm{D}}$ \\
\hline E. indica & $92.626 \pm 8.13^{B}$ & $294.766 \pm 2.70^{C}$ & $11.365 \pm 3.70^{B}$ & $26.82 \pm 5.58^{B C D}$ & $70.606 \pm 9.28^{B}$ & $44.013 \pm 5.45^{\mathrm{F}}$ \\
\hline P. annua & $107.506 \pm 9.60^{A}$ & $102.016 \pm 8.77^{\mathrm{E}}$ & $8.334 \pm 0.03^{B C}$ & $50.793 \pm 9.74^{A}$ & $68.41 \pm 8.97^{\mathrm{B}}$ & $237.8 \pm 8.88^{A}$ \\
\hline D. aegyptium & $85.466 \pm 5.97^{B}$ & $227.133 \pm 4.79^{\mathrm{D}}$ & $22.716 \pm 3.14^{\mathrm{A}}$ & $17.093 \pm 2.43^{\mathrm{D}}$ & $70.296 \pm 9.43^{B}$ & $49.27 \pm 5.60^{\mathrm{EF}}$ \\
\hline S. spontaneum & $53.21 \pm 5.22^{C}$ & $384.2 \pm 9.65^{B}$ & $3.696 \pm 3.30^{\mathrm{D}}$ & $19.963 \pm 4.13^{\mathrm{CD}}$ & $71.57 \pm 8.86^{B}$ & $58.063 \pm 6.90^{\mathrm{E}}$ \\
\hline V. zizanioides & $45.53 \pm 7.75^{C D}$ & $78.48 \pm 7.79^{F}$ & $10.988 \pm 2.62^{\mathrm{B}}$ & $34.206 \pm 7.44^{B}$ & $105.833 \pm 5.15^{\mathrm{A}}$ & $98.706 \pm 8.87^{B}$ \\
\hline 1. cylindrica & $35.686 \pm 7.26^{\mathrm{D}}$ & $408.9 \pm 8.16^{\mathrm{A}}$ & $4.267 \pm 2.45^{\mathrm{CD}}$ & $28.31 \pm 6.85^{B C}$ & $70.96 \pm 8.04^{\mathrm{B}}$ & $86.606 \pm 7.96^{C}$ \\
\hline Ascorbic acid & $16.913 \pm 2.57^{\mathrm{E}}$ & $16.913 \pm 2.57^{G}$ & $2.804 \pm 0.29^{\mathrm{D}}$ & $2.804 \pm 0.29^{E}$ & $32.25 \pm 4.67^{c}$ & $32.25 \pm 4.67^{G}$ \\
\hline
\end{tabular}

Each value in the table is represented as mean $\pm \mathrm{SD}(n=3)$. Values in the same column followed by a different letter (a-g) are significantly different $(p<0.05)$. ( $\mathrm{DPPH}=$ 2,2-diphenyl-1 picrylhydrazyl; ABTS = 2, 2'-azino-bis (3- ethylbenzthiazoline-6-sulphonic acid); SOR Superoxide radical) 


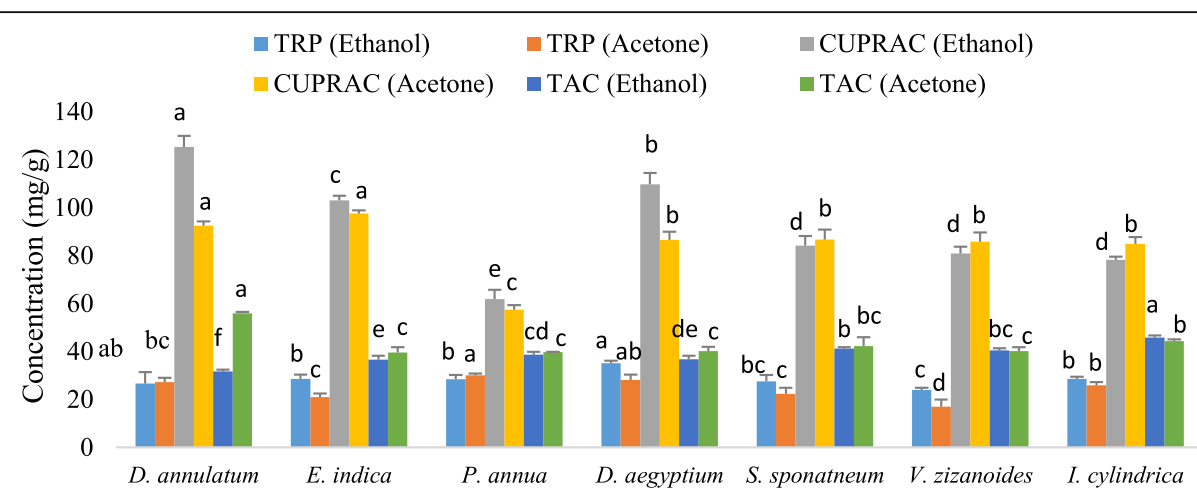

TRP, CUPRAC and TAC of selected plant extracts

Fig. 2 TRP, CUPRAC and TAC of the selected plant extracts. Data represents the mean of three replicates and each letter (a-f) indicates significance at $P<0.05$ (Total reducing power and total antioxidant capacity expressed as ascorbic acid equivalent ( $\mathrm{mg} \mathrm{AE} / \mathrm{g}$ extract); Cupric ions reducing assay expressed as gallic acid equivalent (mg GA/g extract))

Present studies revealed that among both ethanol and acetone plant extracts, DiAEE, DiAAE, DaAEE and DaAAE (AAI- 54.54\%, 43.24\%, 49.13\% and 44.52\%) showed highest relative antioxidant potential while PoAEE and PoAAE (AAI- 41.04\% and 34.11\%) showed poor antioxidant activity. Highest antioxidant activity in $D$. annulatum and $D$. aegyptium was significantly correlated with phytochemicals as they possess maximum phenols and flavonoids contents while $P$. апnиa possess minimum antioxidant potential due to presence of less phenols and flavonoids contents. However, other plant species showed relatively moderate antioxidant potential. Overall, ethanol plant extracts exhibit maximum antioxidant activity as compared to the acetone plant extracts as shown in Fig. 3. It might be due to the chemical compounds present in these species.

\section{DNA damage protection assay}

To access the prevention of oxidative DNA damage by the plant extracts, p1391Z supercoiled DNA was used. Control untreated DNA showed two bands, one of open circular DNA and one of supercoiled DNA. Combine treatment of DNA with Fenton reagent and quercetin (positive control) maintained the supercoiled DNA from scission while treatment of DNA with Fenton reagent in the absence of plant extracts led to the strand scission of the supercoiled DNA. DNA treated with different concentrations of plant extracts showed very little DNA damage protection activity (Fig. 4).

Maximum DNA damage prevention was shown by SaSEE and DiAEE followed by ElIEE while other plants did not reveal any DNA damage preventive activity. It was also noted that ethanol extracts possess greater

\section{$\square$ Acet $\square$ Eth}

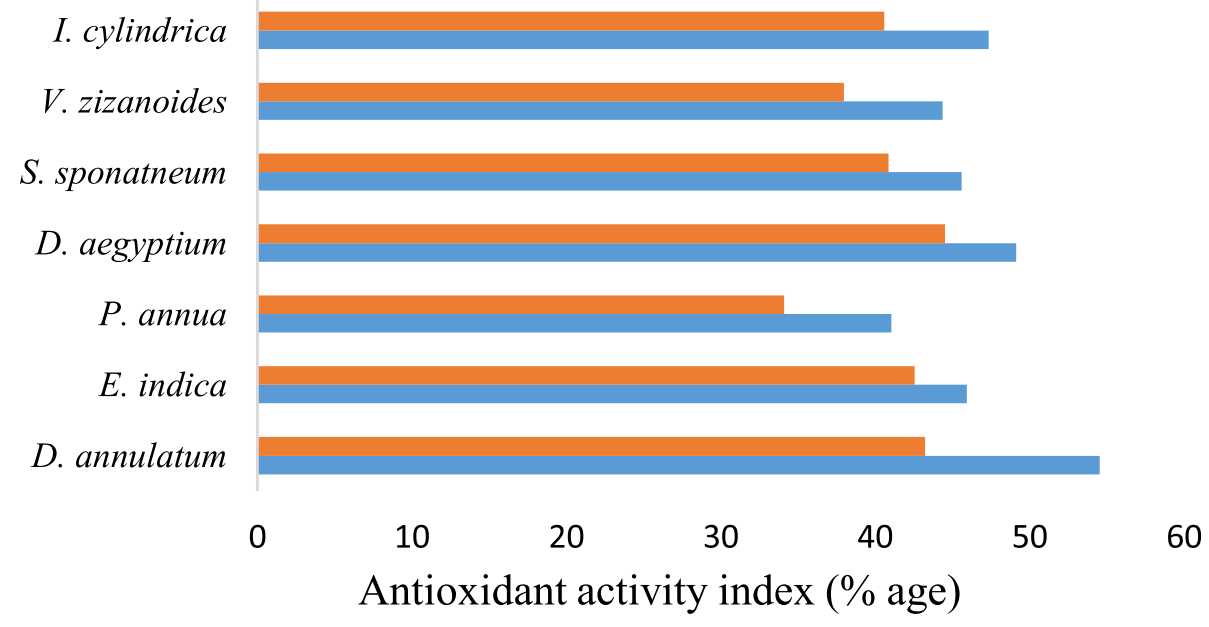

Fig. 3 Antioxidant activity index (AAl) of ethanol and acetone extracts of selected plant species 


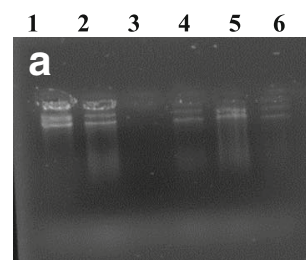

SaSEE

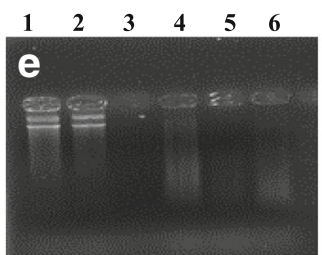

ImCEE

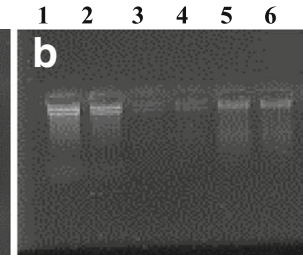

DiAEE

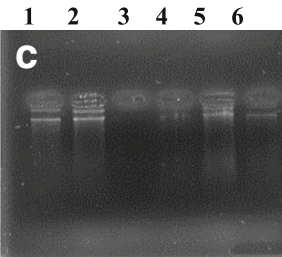

EIIEE

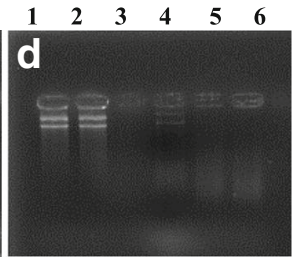

PoAEE

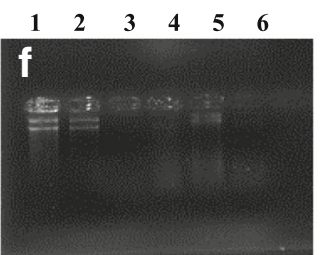

VeZEE

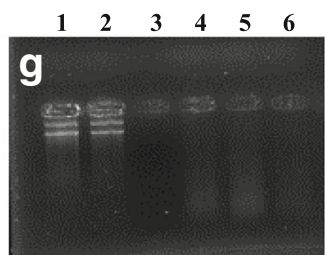

DaAEE

Fig. 4 Effects of the different ethanol plant extracts against oxidative damage to DNA (p1391Z). (Lane 1: Control genomic DNA; Lane 2: Fenton's reagent + DNA; Lane 3: Fenton's reagent + DNA + Quercetin; Lane 4: Fenton's reagent + DNA + $2 \mu \mathrm{l}$ plant extract; Lane 5: Fenton's reagent + DNA $+4 \mu$ l plant extract; Lane 6: Fenton's reagent + DNA $+6 \mu$ l plant extract)

flavonoids and phenols contents so they revealed some DNA damage protection activity while acetone extracts exhibit less phenols and flavonoids contents so they were not found effective for DNA damage protection assay. The DNA damage prevention was increased with increase in plant concentration. Densitometric analysis confirmed the experimental data (Fig. 5).

\section{Antimicrobial assay}

Antimicrobial activity of the plant extracts was observed against nine tested microorganisms. Oxytetracycline was used as a standard drug against bacterial strains and Chloramphenicol was used as a standard drug for fungal strains. No activity was observed against two microorganisms ( $F$. oxysporum and $A$. niger) in both ethanol and acetone plant extracts. Most susceptible organism in the studies was A. flavus followed by B. spizizenii, Mucor specie and $W$. anomalous. The range of minimum inhibitory concentration (MIC) of extracts recorded was 25-75 $\mu \mathrm{g} / \mathrm{ml}$ (Table 3).

In antibacterial activity, majority of the plant extracts showed little or non-significant activity against $S$. aureus, S. typhi and E. coli. Among ethanol plant extracts, ElIEE showed maximum activity (ZOI: $9 \mathrm{~mm}$, AI: 0.321 ) against B. spizizenii while among acetone plant extracts most of the plant species showed maximum antibacterial activity (ZOI: $8 \mathrm{~mm}$, AI: 0.258 ) against some bacterial strains. Among bacterial strains, lowest MIC values $(50 \mu \mathrm{g} / \mathrm{ml})$ were recorded for ElIEE (against B. spizizenii). Similarly, in antifungal activity DaAEE (ZOI: $12 \mathrm{~mm}, \mathrm{AI}: 0.4$ ) as well as DaAAE (ZOI: $11 \mathrm{~mm}$, AI: 0.366) showed maximum activity against $S$. cerevisae as compared to the other plant extracts. However, no inhibition zones were observed against $F$. oxysporum and $A$. niger.

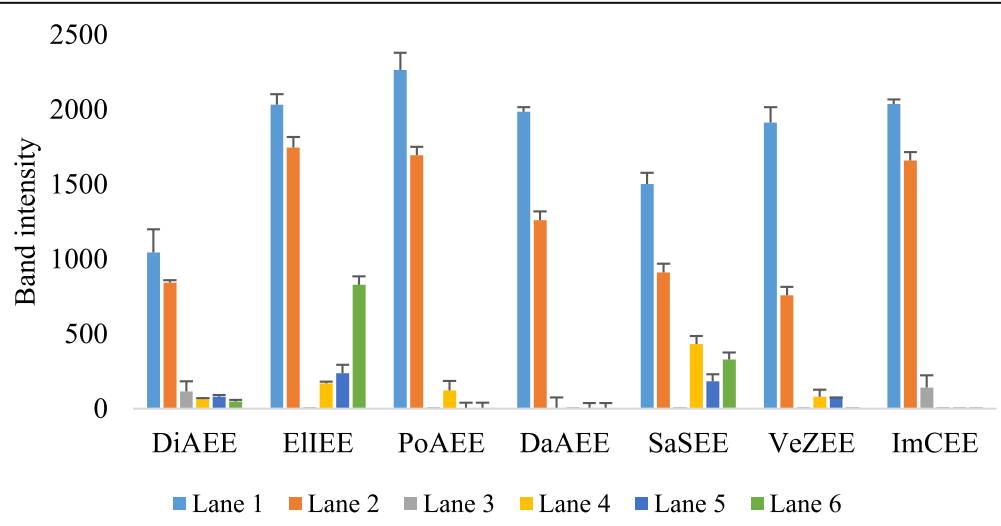

Fig. 5 Band intensity graph of DNA protecting activity. (Lane 1: Control genomic DNA; Lane 2: Fenton's reagent + DNA; Lane 3: Fenton's reagent + DNA + Quercetin; Lane 4: Fenton's reagent + DNA + 2 $\mu$ l plant extract; Lane 5: Fenton's reagent + DNA + $4 \mu$ l plant extract; Lane 6: Fenton's reagent $+\mathrm{DNA}+6 \mu$ l plant extract) 


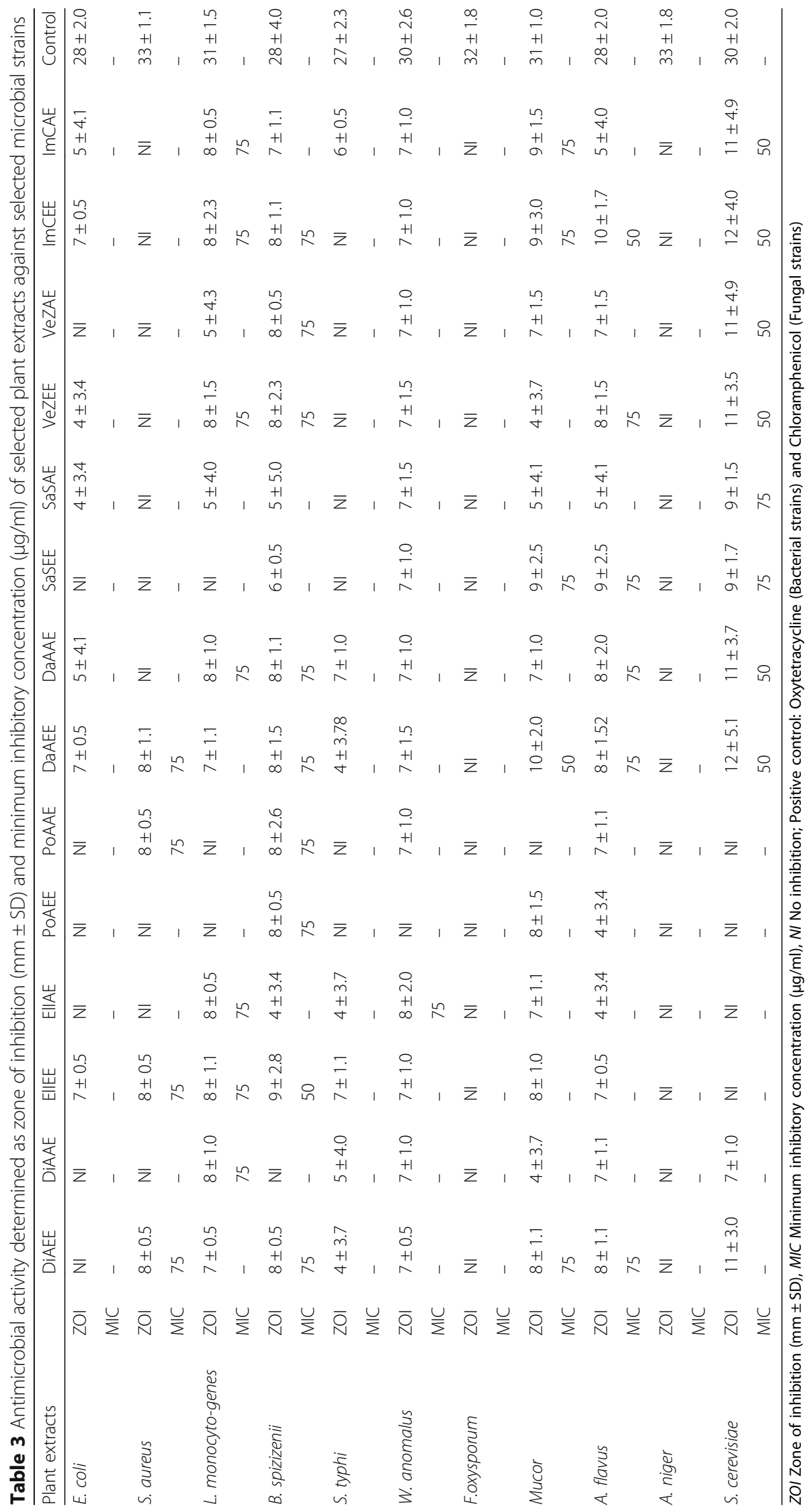


Overall, maximum antimicrobial activities were recorded for DaAEE (i.e against nine tested microbial strains) and DaAAE and ImCAE (i.e against eight microbial strains) and minimum activity was recorded for PoAEE (i.e against three strains only) and PoAAE (i.e against four strains only) respectively. Significant correlation was observed between antimicrobial activity and total phenols and flavonoids contents. As PoAEE and PoAAE possess minimum phenols and flavonoids contents, so they revealed less antimicrobial efficacy. However, remaining plant extracts revealed some activity against few strains as shown in Figs. $6,7$.

\section{Cytotoxic activity}

The ethanol and acetone extracts of the selected plants revealed good brine shrimp cytotoxic activity. Lethal concentration (LC50) in ethanol plant extracts ranged from 11.004 to $20.083 \mathrm{ppm}$ and in case of acetone plant extracts ranged from 7.932 to 23.090 ppm respectively. The degree of lethality was directly related to the concentration of extract. Maximum mortalities (100\%) were observed at a concentration of $250 \mathrm{ppm}$ in both ethanol and acetone extracts. The observed lethality of the plant extracts to brine shrimps revealed the presence of cytotoxic compounds in these plants.

Vincristine sulfate was used as a positive control and its LC50 value was recorded as 0.839 ppm. Results revealed that among ethanol plant extracts, ImCEE, DiAEE and SaSEE (LC50 11.004 ppm, 11.223 ppm and $11.488 \mathrm{ppm}$ ) showed remarkably significant cytotoxic potential and PoAEE (LC50 20.083 ppm) showed minimum cytotoxicity. Whereas remaining ethanol extracts revealed moderate cytotoxic activity. In case of acetone plant extracts, good cytotoxic potential was observed in ImCAE and VeZAE (LC50 7.932 ppm and 8.877 ppm) and least cytotoxic potential was observed in SaSAE
(LC50 23.090). However, other species showed moderate cytotoxic potential (Table 4).

\section{Discussion}

Herbal medicines are considered as one of the most important fields of traditional medicine all over the world. Treatment using natural medicines is gaining attention nowadays because of harmful synthetic additives used by individuals. Sometimes, stem of S. spontaneum is chewed to relieve stomach pain and the whole plant of $D$. annulatum is used for dysentery and manorrhagia [7, 34]. Similarly, the ethnomedicinal importance of E. indica, D. aegyptium, V. zizanoides and I. cylindrica has been well reported [35-39] but the biological activities of majority of these species have not been investigated. Present studies revealed that majority of these species contain various secondary metabolites in varying concentrations (Table 1) as reported by Ratha et al. [39], Abbas et al. [40], Babu and Savithramma [41], Devi and Kottai [42] and Alaekwe [43]. Quantitative analysis revealed that the phenolic contents were found in greater concentration in all plants as compared to the flavonoids contents (Fig. 1). Phenol and flavonoid compounds exhibit inhibitory effects against multiple viruses and bacteria and possess free radical scavenging and anticancer activity. Similarly, saponins have potent antimicrobial, antioxidant and cytotoxic potential in plants [44, 45]. Hundreds of steroids are also present in plants which play crucial role in many disorders such as prostrate cancer. Anthocyanins belong to parent class of molecules called flavonoids and possess significant scavenging activity in plants. Many plants also store chemicals in the form of cardiac glycosides which are used in the treatment of heart diseases while alkaloids have strong antimicrobial efficacy $[46,47]$. Coumarins and terpenoids are active against viruses, bacteria and fungi [48, 49].

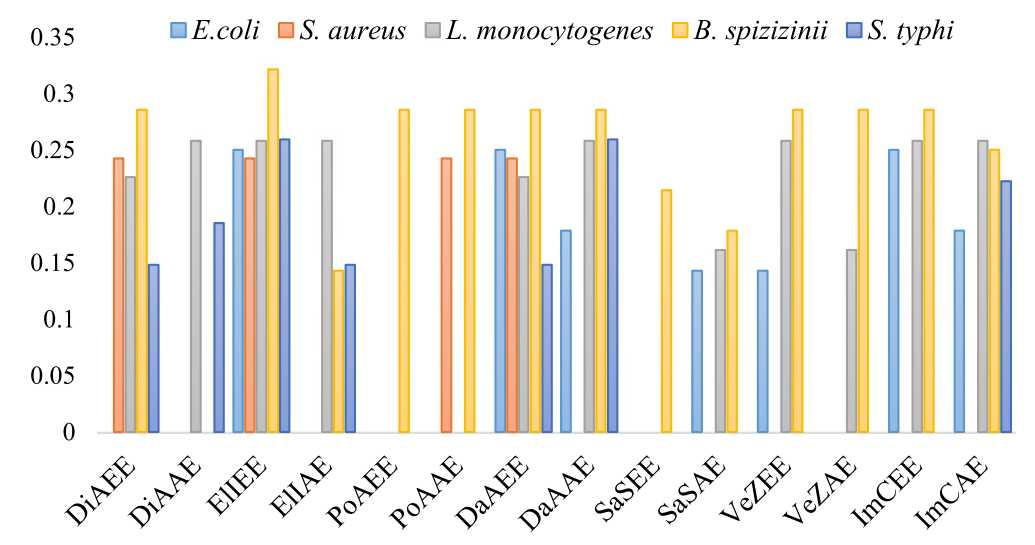

Activity index of Antibacterial Activity

Fig. 6 Activity Index of antibacterial activity of selected ethanol and acetone plant extracts 


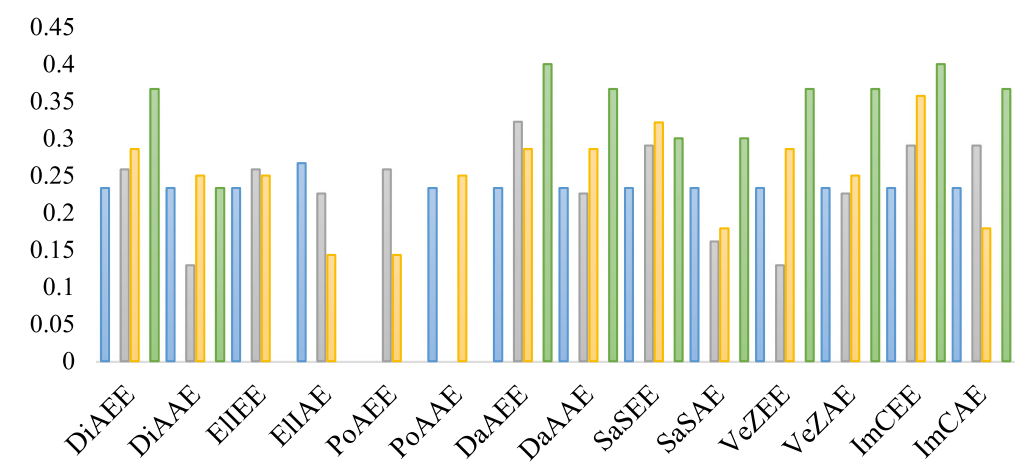

Activity index of Antifungal Activity

Fig. 7 Activity Index of antifungal activity of selected ethanol and acetone plant extracts

Hence, presence of these secondary metabolites in plants indicates significant therapeutic potential in plants.

Natural antioxidants protect us from various diseases by scavenging ROS [50]. Antioxidants in crude plant extracts have multifunctional activities, thus a single antioxidant activity assay might be inadequate to predict and measure the antioxidant efficacy of natural antioxidants. The utilization of assays that measure free radical scavenging activity in combination with reducing power assays is recommended for the determination of natural antioxidant potential. Therefore, six different antioxidant assays, i.e., DPPH, ABTS, SOR, TRP, CUPRAC and phosphomolybdate assays, were conducted to determine the antioxidant efficacy of some commonly occurring grass species. Results revealed that DiAEE, DiAAE, DaAEE and DaAAE (AAI- 54.54\%, 43.24\%, 49.13\% and 44.52\%) showed maximum antioxidant activity while PoAEE and PoAAE (AAI- 41.04\% and 34.11\%) showed least antioxidant activity. However, moderate antioxidant activity was revealed in other plants (Fig. 3). Positive results in all the antioxidant activity assays used in this study indicate that the various compounds in the crude extracts could act as free radicals' scavenger viz., DPPH, ABTS, SOR or possess the reducing power potential of $\mathrm{Fe}^{3+}, \mathrm{Cu}^{2+}$ and Mo (IV) complex. Devi and Kottai [42], Iqbal and Gnanaraj [51] and Rekha and Shivanna [52] also reported antioxidant activity in $S$. spontaneum, $E$. indica and $D$. aegyptium. Intake of such antioxidants

Table 4 Percentage mortality of brine shrimps in probits at five different concentrations and respective LC50 values

\begin{tabular}{|c|c|c|c|c|c|c|c|c|c|c|}
\hline \multirow[t]{2}{*}{ Plant extracts } & \multicolumn{5}{|c|}{ Mortality (\%) in Probits at different doses } & \multirow[t]{2}{*}{ Slope } & \multirow[t]{2}{*}{ Intercept } & \multirow{2}{*}{$\begin{array}{l}\mathrm{R} \\
\text { square }\end{array}$} & \multirow[t]{2}{*}{ LC50 } & \multirow[t]{2}{*}{$95 \% \mathrm{Cl}$} \\
\hline & 6 & 12 & 25 & 50 & 100 & & & & & \\
\hline$\overline{D i A E E}$ & 4.75 & 5.00 & 5.41 & 5.52 & 5.95 & 0.958 & 3.994 & 0.943 & 11.223 & $4.905-25.680$ \\
\hline DiAAE & 4.75 & 4.82 & 5.25 & 5.33 & 6.28 & 1.128 & 3.707 & 0.905 & 14.027 & $7.013-28.058$ \\
\hline EllEE & 4.48 & 4.75 & 5.08 & 5.52 & 6.48 & 1.518 & 3.137 & 0.951 & 16.857 & $9.783-29.043$ \\
\hline EllAE & 4.90 & 5.15 & 5.25 & 5.71 & 6.75 & 1.319 & 3.691 & 0.910 & 9.828 & $5.256-18.378$ \\
\hline POAEE & 4.48 & 4.56 & 5.08 & 5.25 & 6.28 & 1.358 & 3.231 & 0.925 & 20.083 & $11.206-35.992$ \\
\hline POAAE & 4.48 & 4.75 & 5.25 & 5.33 & 6.28 & 1.341 & 3.343 & 0.940 & 17.220 & $9.444-31.398$ \\
\hline DaAEE & 4.26 & 4.90 & 5.08 & 5.25 & 6.28 & 1.398 & 3.197 & 0.931 & 19.455 & $10.940-34.597$ \\
\hline DaAAE & 4.64 & 4.90 & 5.25 & 5.41 & 6.75 & 1.439 & 3.354 & 0.900 & 13.936 & $7.977-24.346$ \\
\hline SaSEE & 4.75 & 5.15 & 5.25 & 5.33 & 6.28 & 1.020 & 3.918 & 0.886 & 11.488 & $5.361-24.618$ \\
\hline SaSAE & 3.87 & 4.75 & 5.00 & 5.52 & - & 1.673 & 2.719 & 0.969 & 23.090 & 13.974-38.155 \\
\hline VeZEE & 4.64 & 4.90 & 5.15 & 5.61 & 6.75 & 1.532 & 3.256 & 0.929 & 13.749 & $8.002-23.624$ \\
\hline VeZAE & 4.90 & 5.00 & 5.52 & 5.84 & - & 1.089 & 3.967 & 0.956 & 8.877 & 4.153-18.972 \\
\hline ImCEE & 4.75 & 5.15 & 5.25 & 5.61 & 6.48 & 1.245 & 3.704 & 0.933 & 11.004 & $5.698-21.251$ \\
\hline ImCAE & 5.00 & 5.25 & 5.41 & 5.84 & 6.75 & 1.286 & 3.844 & 0.929 & 7.932 & $4.095-15.366$ \\
\hline
\end{tabular}

LC50 Lethal concentration fifty, Cl Confidence interval 
protect the body from damage caused by harmful molecules such as free radicals, ultimately lowering the risk of infections and some forms of cancer and so, improves the health.

Hydroxyl radicals may also cause DNA strand breakage, which may further cause mutagenesis, carcinogenesis and cytotoxicity [47]. DNA protective activity of selected plant extracts was assessed on DNA strand breakage using genomic DNA. Different concentration of plant extracts was treated with fenton's reagent and DNA bands were analyzed. Band intensity was also measured to check the effectiveness of plants (Fig. 5). The results proved that SaSEE, DiAEE and ElIEE protects DNA from damage while other species didn't exhibit DNA protecting activity. Present results are in accord with those of Sagnia et al. [53] who confirmed that ElIEE possess significant superoxide radical scavenging activity and has ability to protect DNA damage. Keeping in mind the toxic effects produced by different solvents used for extraction, ethanol was carefully chosen to check the DNA protection ability of plants as the ethanol extraction product mainly contains high hydrophilic compounds and hence possess less toxic effects to living cells.

Antimicrobial is an agent that destroy or inhibits the growth of microbes such as bacteria, fungi, or viruses, as well as protozoans. Hence, now-a-days antimicrobials of plant origin are generally recommended as they are more effective in treatment of infectious diseases simultaneously alleviating many side effects which are associated with synthetic antibiotics [54]. The antimicrobial activity was performed by agar disc diffusion method. Results revealed that most of the plant extracts were more active against $L$. monocytogenes, $W$. anomalous, $A$. flavus and Mucor specie while S. aureus, F. oxysporum and $A$. niger were revealed as highly resistant pathogens. Overall, all plant extracts showed moderate to weak activity against most of the tested pathogens (Table 3). These results are supported by the findings of Parkavi et al. [55] and Kumar et al. [10] who revealed significant antibacterial activity of ImCEE and DaAEE against $E$. coli. Similarly, Fazal et al. [56] also reported the antimicrobial efficacy of VeZEE. Moreover, Morah and Otuk [57] documented significant activity of the ElIEE against E. coli, S. typhi and S. aureus. Crude extracts of these plants can be used as an alternative drug to control food poisoning and other infectious diseases caused by resistant microbes and to preserve foodstuff as well.

Cytotoxic drugs are highly toxic to cells, especially through their action on cell reproduction. These drugs are increasingly being used for the treatment of cancer, multiple sclerosis, autoimmune disorders and many other diseases. Cytotoxic materials are generally identified by a purple symbol that shows a cell in late telophase [58]. It was interest of this study to determine cytotoxicity activity of these species using brine shrimp lethality test as it is considered as the inexpensive, rapid and simple bioassay for cytotoxicity study of the plant extracts. Previous literature [59] provides strong evidence that plant extracts with LC50 values below $20 \mu \mathrm{g} /$ $\mathrm{ml}$ have more probability of producing anticancer compounds. In present studies, all plant extracts revealed strong to moderate cytotoxic potential (Table 4). These results are supported by the findings of Wong et al. [60] and Responte al et. [61] who demonstrated brine shrimps' cytotoxic potential in I. cylindrica and E. indica. The cytotoxicity exhibited by the crude extracts indicates the presence of active or potent bioactive compounds in plants which reveals that they possess significant antifungal effects, antibacterial effects and other pesticidal effects.

\section{Conclusion}

Reactive oxygen species (ROS) play an important role in oxidative DNA damage which may causes dysfunction in biological processes in the human body leading to many chronic diseases. Use of herbal medicines to treat different diseases is also preferred as these are cheap, safe and without any harmful side-effects as compared to the synthetic drugs. Similarly, the replacement of synthetic drugs with natural antioxidants may be valuable. To date, biological potential of many grasses of Bahawalpur region have not been evaluated. Hence, in present studies, biological potential of aerial parts of some grasses was checked and comparison among ethanol (polar solvent) and acetone (semi-polar solvent) extracts was made. Results revealed that aerial parts of D. annulatum, D. aegyptium, I. cylindrica, E. indica, S. spontaneum and V. zizanioides possess good antioxidant and antimicrobial activity while $P$. аnnua did not show significant biological potential. Maximum activities were observed in their ethanol plant extracts as compared to the acetone plant extracts as ethanol extract has greater ability to dissolve polar substances. This study provides experimental evidence that the extracts of these species can be used in crude form to combat various bacterial and fungal infections and can be used as natural antioxidants as well. So, these species possess vital medicinal value rather than being utilized by local individuals and as forage for horses and camels. Selected species contain various secondary metabolites which can be the major contributor to their antibacterial, antifungal, antioxidant and brine shrimps' cytotoxic activities. These compounds can also be isolated from crude extracts for use in medicinal drugs. However, they are revealed as less effective for DNA damage protection assay. In future, there is a need of establishing a more systemic study to validate the human consumption of selected species for medicinal use through additional toxicity and isolation and characterization of principle active compounds via HPLC and NMR spectroscopy techniques. 


\section{Abbreviations}

AAl: Antioxidant activity index; ABTS: 2,2'-azino-bis (3-ethylbenzothiazoline-6sulphonic acid); ANOVA: Analysis of variance; ATCC: American type culture collection; BC: Before christ; Cl: Confidence interval; CNS: Central nervous system; $\mathrm{Cu}^{2+}$ : Copper; $\mathrm{CuCl}_{2}$ : Cupric chloride; CUPRAC: Cupric reducing antioxidant capacity; DaAAE: Dactyloctenium aegyptium acetone extract; DaAEE: Dactyloctenium aegyptium ethanol extract; $\mathrm{dH}_{2} \mathrm{O}$ : Distilled water; DiAAE: Dicanthium annulatum acetone extract; DiAEE: Dicanthium annulatum ethanol extract; DNA: Deoxyribonucleic acid; DPPH: 2,2-diphenyl-1picrylhydrazyl; EDTA: Ethylenediaminetetraacetic acid; EllAE: Eleusine indica acetone extract; ElIEE: Eleusine indica ethanol extract; ELISA: Enzyme-linked immunosorbent assay; $\mathrm{Fe}^{3+}$ : Iron; $\mathrm{FeCl}_{3}$ : Ferric chloride; GAE: Gallic acid equivalent; HPLC: High-performance liquid chromatography; IC50: Half maximal inhibitory concentration; ImCAE: Imperata cylindrica acetone extract; ImCEE: Imperata cylindrica ethanol extract; LC50: Fifty/median lethal concentration; LSD: Least significant difference; MIC: Minimal inhibitory concentration; mM: Millimolar; Mo: Molybdenum; NaCO3: Sodium carbonate; NBT: Nitro-blue tetrazolium; NMR: Nuclear magnetic resonance spectroscopy; PoAAE: Poa annua acetone extract; PoAEE: Poa annua ethanol extract; Ppm: Parts per million; QE: Quercetin equivalent; ROS: Reactive oxygen species; SaSAE: Saccharum spontaneum acetone extract; SaSEE: Saccharum spontaneum ethanol extract; SDA: Sabouraud dextrose agar; SOR: Superoxide radical scavenging assay; TAC: Total antioxidant capacity; TCA: Trichloroacetic acid; TFC: Total flavonoid contents; TPC: Total phenol contents; TRP: Total reducing power; VeZAE: Vetiveria zizanioides acetone extract; VeZEE: Vetiveria zizanioides ethanol extract; ZOl: Zone of inhibition; $\mu$ l: Microliter

\section{Acknowledgements}

The authors would like to thank Dr. Imdad Ullah for providing help and support to conduct this research.

\section{Funding}

No funding source available.

\section{Availability of data and materials}

All data generated or analyzed during this study are included in this manuscript.

\section{Authors' contributions}

TM and SK formed the idea and supervised the studies. SK provided the knowledge of fodder grasses. TM provided all experimental facilities. IF performed the experiments and wrote the manuscript. All authors read and approved the final manuscript.

\section{Authors' information}

Plant Biochemistry and Molecular Biology, Quaid-e-Azam University Islamabad, Pakistan.

\section{Ethics approval and consent to participate}

Not applicable.

\section{Consent for publication}

Not applicable.

\section{Competing interests}

The authors declare that they have no competing interests.

\section{Publisher's Note}

Springer Nature remains neutral with regard to jurisdictional claims in published maps and institutional affiliations.

\section{Author details}

${ }^{1}$ Department of Plant Sciences, Faculty of Biological Sciences, Quaid-i-Azam University, Islamabad 45320, Pakistan. ${ }^{2}$ Department of Zoology, University of Gujrat Sub-Campus Rawalpindi, Gujrat, Pakistan.
Received: 26 August 2017 Accepted: 15 January 2018

Published online: 24 January 2018

\section{References}

1. Shah GM, Khan MA. Check list of medicinal plants of Siran Valley Mansehra Pakistan. Ethnobot Leaflets. 2006;10:63-71.

2. Gillani AH. History of Bahawalpur state and its culture. Pak J Soc Sci. 2014; 34(2):463-71.

3. Hsiao C, Jacobs SWL, Barker NP, Chatterton NJ. A molecular phylogeny of the subfamily Arundinoideae (Poaceae) based on sequences of rDNA. Aust Syst Bot. 1998;11:41-52.

4. Cope TA. Poaceae. In: Nasir E, Ali SI, editors. Flora of Pakistan, vol. 143; 1982. p. 26-7. Karachi.

5. Moreira FV, Bastos JF, Blank AF, Alves PB, Santos MR. Chemical composition and cardiovascular effects induced by the essential oil of Cymbopogon citratus DC. Stapf, Poaceae, in rats. Rev Bras. 2010;20(6):904-9.

6. Kumar D, Seth R, Natarajan S, Dwivedi GK, Shivay YS. Seed yield response of marvel grass (Dichanthium annulatum) to cutting management and nitrogen fertilization in central India. Agron Res. 2008;6:499-509.

7. Nisar MF, Farrukh J, Muhammad W, Sajil I, Yasmin T, Syed MH, Julia LZ. Ethno-medicinal uses of plants from district Bahawalpur, Pakistan. Curr Res J Biol Sci. 2014;6(5):183-90.

8. Hansakul P, Ngamkitidechakul C, Ingkaninan K, Sireeratawong S, Panunto W. Apoptotic induction activity of Dactyloctenium aegyptium (L.) P.B. And Eleusine indica (L.) Gaerth. Extracts on human lung and cervical cancer cell lines. Songklanakarin J Sci Technol. 2009;31:273-9.

9. Ettebong EO, Nwafor PA, Okokon JE. In vivo antiplasmodial activities of ethanolic extract and fractions of Eleusine indica. Asian Pac J Trop Med. 2012;5:673-6.

10. Kumar V, Rauf FB, Sulthana B, Satish MK, Mangilal T. Evaluation of antimicrobial activity of ethanolic extract of Dactyloctenium aegyptium. Int J Pharm Res. 2015 5(12):338-43.

11. Khalid MH, Siddiqui H. Pharmacognostical evaluation and qualitative analysis of Saccharum spontaneum (Linn.) root. Int J Pharm Sci Drug Res. 2001;3(4):338-41.

12. Kumar CA, Varadharajan R, Muthumani P, Meera R, Devi P, Kameswari B. Psychopharmacological studies on the stem of Saccharum spontaneum. Int J Pharm Tech Res. 2010;2(1):319-21.

13. Sathya M, Kokilavani R. Antiurolithiatic activity of ethanolic root extract of Saccharum spontaneum on glycolic acid induced urolithiasis in rats. J Drug Deliv Therapeut. 2012;2(5):86-9.

14. Ghani A. Asiatic Society of Bangladesh, Dhaka. Bangladesh. 2003:425-6.

15. Kritikar KR, Basu BD. Indian M Nadkarni KM. Indian plants and drugs with their medicinal properties and uses. New Delhi: Asiatic publishing House; 2001.

16. Sushama B, Nishteswar K. Review of anti-oxidant herbal drugs w.S.R to madhuraskandha (charakasamhita). Int J Ayurvedic Herbal Med. 2014;4: 1480-93.

17. Doshi GM, Une HD, Shanbhag PP. Rasayans and non-rasayans herbs: Future immunodrug - Targets. Pharmacogn Rev. 2013;7(14):92-6.

18. Harborne JB. Phytochemical methods. A guide to modern techniques of plant analysis. London, New York: Chapman and Hall Ltd.; 1973. p. 49-188.

19. Raman N. Phytochemical technique. New Delhi: New Indian Publishing Agencies; 2006. p. 19.

20. Chlopicka J, Pasko P, Gorinstein S, Jedryas A, Zagrodzki P. Total phenolic and total flavonoid content, antioxidant activity and sensory evaluation of pseudocereal breads. LWT-Food Sci Technol. 2012:46:548-55.

21. Chang CC, Yang MH, Wen HM, Chern JC. Estimation of total flavonoid content in propolis by two complementary colorimetric methods. J Food Drug Anal. 2002;10:178-82.

22. Brand-Williams W, Cuvelier ME, Berset CL. Use of a free radical method to evaluate antioxidant activity. Food Sci Technol. 1995;28:25-30.

23. Arnao MB. Some methodological problems in the determination of antioxidant activity using chromogen radicals: a practical case. Trends Food Sci Tech. 2001;11:419-21.

24. Oyaizu M. Studies on product of browning reaction prepared from glucose amine. J Nutr. 1986;44:307-15.

25. Apak R, Guculu KG, Ozyurek M, Karademir SE. Novel total antioxidant capacity index for dietary polyphenols and vitamins $C$ and $E$, using their cupric iron reducing capability in the presence of neocuproine: CUPRAC method. J Agric Food Chem. 2004;52:7970-81. 
26. Prieto $P$, Pineda M, Aguilar M. Spectrophotometric quantitation of antioxidant capacity through the formation of a phosphomolybdenum complex: specific application to the determination of vitamin E. Anal Biochem. 1999:269(2):337-41.

27. Puttaraju NG, Sathisha UV, Shylaja MD, Shashirekha MNU, Rajathnam S. Antioxidant activity of indigenous edible mushrooms. J Agric Food Chem. 2006:54:9764-72

28. Lee JC, Kim HR, Kim J, Jang YS. Antioxidant property of an ethanol extract of the stem of Opuntia ficus-indica Var. saboten. J Agric Food Chem. 2002;50(22):6490-6.

29. Bauer AW, Kirby WM, Sherries JC, Tuck M. Antibiotic susceptibility testing by a standardized disc diffusion method. Amer J Clinic Pathol. 1996;45:493-6.

30. Ronald MA. Microbiologia. Compania Editorial Continental S.A. de C.V. Mexico, D. F. 1990; 505.

31. Meyer AA, Hartmann H, Sumpel F, Cruetzfeld W. Mechanism of insulin resistance in CCl4-induced cirrhosis of rats. Gastroenterology. 1992;102:223-9.

32. Steel RGD, Torrie JH, Dickey DA. Principles and procedures of statistics: a biometrical approach. 3rd ed. New York: McGraw Hill Co; 1996.

33. Finney DJ. Probit analysis (2nd ed.). J Inst Actuaries. 1952;78(3):388-90.

34. Lapuz AMR, Arabiran RDA, Sembrano TM, Albaniel JR, Paet JC, Maini HA. Preformulation and evaluation of antibacterial and anti-inflammatory activities of Saccharum spontaneum Linn. Root extract cream. Int J Chem Eng Appl. 2016;7(3):204-8.

35. Balasankar D, Vanilarasu K, Preetha PS, Rajeswari S, Umadevi M, Bhowmik D. Traditional and medicinal uses of Vetiver. J Med Plants Stud. 2013;1 (3):191-200.

36. Khan AV, Ahmed Q, Khan AA, Shukla I. In vitro antibacterial efficacy of some important traditional medicinal plants in India against Escherichia coli and Staphylococcus aureus strains. J Med Plants Res. 2013;7(7):329-38.

37. Biswas KR, Khan T, Monalisa MN, Swarna A, Ishika T, Rahman M, Rahmatullah M. Medicinal plants used by folk medicinal practitioners of four adjoining villages of Narail and Jessore districts, Bangladesh. Am Eurasian J Sustain Agric. 2011;5(1):23-33.

38. Namukobea J, Kasenene JM, Kiremirea BT, Byamukamaa R, KamatenesiMugisha M, Krief S, Dumontet V, Kabasa JD. Traditional plants used for medicinal purposes by local communities around the northern sector of Kibale National Park, Uganda. J Ethnopharmacol. 2011;136:236-45.

39. Ratha M, Subha K, Senthilkumar G. Panneerselvam.A. Screening of phytochemical and antibacterial activity of Hemidesmus indicus (L.) and Vetiveria zizanioides (L.). Euro J Exp Biol. 2012;2(2):363-8.

40. Abbas MN, Shahnaz AR, Muhammad M, Nureen R, Munawar I. Phytochemical constituents of weeds: baseline study in mixed crop zone agroecosystem. Pak J Weed Sci Res. 2013;19(2):231-8.

41. Babu RH, Savithramma N. Phytochemical screening of underutilized species of Poaceae. An Int J. 2013:1(10):947-51.

42. Devi AlJ, Kottai MA. Phytochemical screening, antioxidant activities and total phenolic content of ethanolic extract from whole plant of Saccharum spontaneum (Linn.). Int J Chem Pharm Sci. 2014;5(2):112-8.

43. Alaekwe IO, Ajiwe VIE, Ajiwe AC, Aningo GN. Phytochemical and anti microbial screening of the aerial parts of Eleusine indica. Int J Pure App Biosci. 2015;3(1):257-64.

44. Montoro P, Braca A, Pizza C, De Tommasi N. Structure-antioxidant activity relationships of flavonoids isolated from different plant species. Food Chem. 2005:92:349-55.

45. Negi JS, Negi PS, Pant GJ, Rawat MSM, Negi SK. Naturally occurring saponins: chemistry and biology. J Pois Med Plant Res. 2013;1(1):001-6.

46. Aniszewski T. Alkaloids-Secrets of life alkaloid chemistry, biological significance, applications and ecological role. First edition. The Boulevard, Langford Lane, Kidlington, Oxford: Elsevier; 2007.

47. Miguel MG. Anthocyanins: antioxidant and/or anti-inflammatory activities. J Appl Pharm Sci. 2011;01(06):07-15.

48. Taylor RSL, Edel F, Manandhar NP, Towers GHN. Antimicrobial activities of southern Nepalese medicinal plants. J Ethnopharmacol. 1996;50:97-102.

49. Xu HX, Zeng FQ, Wan M, Sim KY. Anti-HIV triterpene acids from Geum japonicum. J Nat Prod. 1996;59:643-5.

50. Umamaheswari M, Chatterjee TK. In vitro antioxidant activities of the fractions of Coccinnia grandis L. leaf extract. Afr J Trad Comp Altern Med. 2008:5:61-73.

51. Iqbal M, Gnanaraj C. Eleusine indica L. possess antioxidant activity and precludes carbon tetrachloride (CCl4)- mediated oxidative hepatic damage in rats. Environ Health Prev Med. 2012;17(4):307-15.
52. Rekha D, Shivanna MB. Diversity, antimicrobial and antioxidant activities of fungal endophytes in Cynodon dactylon (L.) Pers. and Dactyloctenium aegyptium (L.) P. Beauv. Int J Curr Microbiol App Sci. 2014;3(8):573-91.

53. Sagnia B, Donatella F, Rita C, Carla M, Giancarlo F, Vittorio C. Antioxidant and anti-inflammatory activities of extracts from Cassia alata, Eleusine indica, Eremomastax speciosa, Carica papaya and Polyscias fulva medicinal plants collected in Cameroon. PLoS One. 2014;9(8):1-10.

54. Manos J, Belas R. The Genera Proteus, Providencia, and Morganella. Prokaryotes. Chapter 3.3.12. 2006; 6: 245-269.

55. Parkavi V, Vignesh M, Selvakumar K, Muthu JM, Joysa JR. Antibacterial activity of aerial parts of Imperata cylindrica $(\mathrm{L})$ Beauv. Int J Pharm Sci Drug Res. 2012;4(3):209-12.

56. Fazal H, Nisar A, Bilal HA, Naaz A. Selected medicinal plants used in herbal industries; their toxicity against pathogenic microoraganisms. Pak J Bot. 2012:44(3):1103-9.

57. Morah F, Otuk ME. Antimicrobial and anthelmintic activity of Eleusine indica. Acta Scientiae et Intellectus. 2015;1(4):28-32.

58. Edgar-Hughes E, Boss K, Coulls S, Williams R, Walsh A, Hofmanis E, Stevenson B, Adams J, Ng M, Wu L, et al. Safe handling cytotoxic drugs and related waste. Adelaide: South Australia Department of Health; 2012.

59. Ali A, Haider MS, Hanif S, Akhtar N. Assessment of the antibacterial activity of Cuscuta pedicellata Ledeb. Afr J Biotechnol. 2014;13:430-3.

60. Wong FC, Tsun-Thai C, Yee-Wei H. Antioxidation and cytotoxic activities of selected medicinal herbs used in Malaysia. J Med Plants Res. 2012;6(16): 3169-75.

61. Responte MA, Maria R, Dacar B, Olga MN, Mylene MU. Brine shrimp lethality assay of whole plant extracts of Eleusine indica. Adv Agric Botanics Int J Bioflux Soc. 2015:7(2):90-5.

\section{Submit your next manuscript to BioMed Central and we will help you at every step:}

- We accept pre-submission inquiries

- Our selector tool helps you to find the most relevant journal

- We provide round the clock customer support

- Convenient online submission

- Thorough peer review

- Inclusion in PubMed and all major indexing services

- Maximum visibility for your research

Submit your manuscript at www.biomedcentral.com/submit 